\title{
Development and Characterization of Nano-Sized Emulsion Systems Incorporated Polyphenolic Compound for Application Through the Skin
}

\author{
Bülent SAMANCI ${ }^{*}$ (D), Fatma Gülgün YENER $^{* *}$ (D), İsmail Tuncer DEĞİM ${ }^{* * *}$ D
}

Development and Characterization of Nano-Sized

Emulsion Systems Incorporated Polyphenolic Compound for Application Through the Skin

\section{SUMMARY}

In addition to having strong anti-oxidant properties, resveratrol has anti-cancer, anti-angiogenic, cardioprotective, anti-diabetic, antiviral, and neuroprotective activities. Despite its rapid absorption, first-pass effect and intestinal metabolism reduce the bioavailability of resveratrol. Moreover, the lipophilic property of resveratrol reduces its water solubility and metabolized in high incidence reduces its oral bioavailability. Therefore, it was aimed to develop an optimum formulation for the skin application of resveratrol to overcome the negatives after oral administration. Since their easy formulation, thermodynamically stable properties, and facilitating the delivery of both lipophilic and hydrophilic active ingredients, loading resveratrol to microemulsions (MEs) will be a suitable delivery system to overcome the drawback of stability problems and skin bioavailability of resveratrol. A Triangle phase diagram was constructed, and the MEs region was determined by points studies. Subsequently, some formulations were selected within the transparent region by considering characteristics required to achieve optimized transdermal drug delivery. Chosen formulations were exposed to pre-stability tests such as centrifuge and thermal stress tests. Characterization studies such as droplet size, size distribution, zeta potential, viscosity, $p H$ measurement were performed on remained intact formulations after pre-stability tests. In terms of the characterization test results such as $p H$, viscosity, conductivity, there wasn't found significant difference observed between formulations. However, polydispersity index and zeta potential values provided to choosing optimal formulation.

Key Words: Microemulsion, Penetration enhancers, Resveratrol, Transdermal Drug delivery, Triangle phase diagrams
Deriden Uygulama İçin Polifenolik Bileşik İçeren Nano Boyutlu Emülsiyon Sistemlerinin Geliştirilmesi ve Karakterizasyonu

$\ddot{O Z Z}$

Resveratrol güçlü bir antioksidan özelliğe sahip olmasının yanı sıra antikanser, anti-anjiyojenik, kardiyoprotektif, anti-diyabetik, anti-viral ve nöroprotektif aktivitelere sahiptir. Insan vücudunda hizle emilime uğramasına rağmen, bağırsak ve karaciğer metabolizmast, resveratrolün sistemik biyoyararlanım için hiz sinırlayıcıdırlar. Ayruca, resveratrolün yüksek lipofilikliği, suda çözünürlüğ̈̈nü ve oral yoldan yüksek oranda metabolize edilmesi nedeni ile oral biyoyararlanımın azaltır. Bu nedenle, oral uygulama ile görülen olumsuzluklarn üstesinden gelmek için resveratrolün deri uygulamast için optimum bir formülasyon geliştirilmesi amaçlanmıştır.Kolay formüle edilebilmeleri, termodinamik olarak kararl olmaları ve hem lipofilik hem de hidrofilik etkin maddelerin vücuda verilmesini kolaylaştırmalarından dolayı, resveratrolün mikroemülsiyonlara (MEler) yüklenmesi, stabilite sorunlar ve deriden emiliminin zor olmast gibi dezavantajlarının üstesinden gelmek için uygun bir ilaç taşııııı sistemi olacaktır.Bu çalışmada önce ücgen faz diyagramı oluşturularak MEs bölgesi noktasal çalş̧̧ ile belirlendi. Daha sonra optimize edilmiş formülasyonu elde etmek için gerekli ozzellikler göz önünde bulundurularak ME sistemleri oluşturan bölge içinde bazı formülasyonları seçildi. Seçilen formülasyonlar, santrifïj ve termal stres testleri gibi ön stabilite testlerine tabi tutuldu. Damlacık boyutu, damlacık boyut dağgllmi, zeta potansiyeli, viskozite, pH ölçümü gibi karakterizasyon çalı̧maları, ön stabilite testlerinden sonra fiziksel olarak bozulmadan kalan formülasyonlar üzerinde gerçekleștirildi. Viskozite, $p H$, iletkenlik gibi karakterizasyon testleri sonuçları açısından formülasyonlar transdermal uygulamalar için kabul edilebilir aralıktaydt. Ancak damlacık boyutu, polidispersite indeksi ve zeta potansiyel değerleri optimal formülasyonun belirlenmesini să̆lamıştır.

Anabtar Kelimeler: Mikroemülsiyon, Penetrasyon artıricular, Resveratrol, Transdermal taşıyıcı sistemler, Ücgen Faz Diyagramı

ORCID: 0000-0002-7198-5375, Istanbul University, Department of Pharmaceutical Technology, Istanbul, Turkey

"* ORCID: 0000-0002-7234-0034, Istanbul University, Department of Pharmaceutical Technology, Istanbul, Turkey

-... ORCID: 0000-0002-9329-4698, Biruni University, Department of Pharmaceutical Technology, Istanbul, Turkey 


\section{INTRODUCTION}

The skin is the largest organ that protects living and vital organs from outer hazardous that are considered causes of pathological developments (Juškaitė, 2015). The average weight of skin comprises $10 \%$ of body weight, and surface area is about $1.7 \mathrm{~m}^{2}$, in adults (Benson, 2012).

There are many skin deteriorations such as skin cancer, erythema, and skin aging induced by UV radiation from the sun (Fisher, 1997). Due to some advantages such as low-risk side effects, avoiding the firstpass effect, and prevent active substances from gastrointestinal tract degradations, topical and transdermal delivery systems become more widespread in the therapy of skin diseases (Ambade, 2008). Providing drug delivery to a localized skin area is achieved by topical delivery systems (Ambade, 2008). Topical delivery of active ingredients into the skin could be considered as one of the possible treatment methods. On the other hand, when the drug is delivered through the skin into the systemic circulation, these drug delivery systems are considered the transdermal group. However, the outer layer of the skin the stratum corneum (SC) besides protecting the body against external influences and consists of an obstacle to drug administration to the skin. To enhance skin penetration of active substances, physical and chemical penetration enhancers can be used. Due to their low cost, ease of use, safety, and efficacy fatty acids, fatty esters, surfactants, and terpenes have attracted attention and considered chemical skin penetration enhancers (Trommer \& Neubert, 2006). Additionally, nano-sized innovative drug delivery systems such as microemulsions (MEs), nanoemulsions (NEs), nanoparticles (NPs), liposomes are more suitable in terms of the effective delivery of an active substance into the skin layer compare to traditional drug delivery systems such as macro emulsions, gel, solutions (Patravale, 2008; Surber, 2017).
Because they are easy to formulate, have thermodynamically stable properties, and facilitate the delivery of both lipophilic and hydrophilic active ingredients, MEs promise drug delivery systems for transdermal delivery (Kreilgaard, 2002; Lawrence, 2012). MEs are single-phase, optically isotropic nano-structured solutions that have three main components that consist of the oily phase, aqueous phase, and surfactant (Liu, 2011). Since the droplet size of the dispersed phase is not bigger than one-fourth of the wavelength of visible light ( $<150 \mathrm{~nm}$ ), ME systems are observed as transparent (Singh, 2010). ME components according to their quantities and types have an impact on the formulation's droplet size and viscosity, thus affects drug penetration (Juškaité, 2015).

Resveratrol (trans-3, 5, 4'-trihydroxystilbene) is a plant-originated active, which is a natural polyphenolic phytoalexin (Baur \& Sinclair, 2006). Resveratrol has some pharmacological activities such as anti-oxidant, cardioprotective, chemopreventive, anti-inflammatory, analgesic, neuroprotective, and anti-cancer (Baur, 2006; Delmas, 2006; Jang, 1997). Various resveratrol formulation has been developed for systemic therapeutic (Das, 2011; Das, 2010a, 2010b, 2010c; Das, 2010). In addition, resveratrol has some improving effects on the skin such as anti-aging, anti-inflammatory, strengthening of skin's natural anti-oxidant, photo-protective effects, prevention of oxidative stress-induced collagen damage, and protection from UV that induce skin cancer and, sunburn (Baxter, 2008; Ndiaye, 2011; Zillich, 2015). Recently, since there is significantly increased attractiveness to the natural-based agents in skincare, resveratrol is in demand among skincare products. Poor aqueous solubility and low oral bioavailability are disadvantages of resveratrol (Das, 2008). Transdermal resveratrol ME formulations may be able to overcome solubility and skin bioavailability problems. However, due to 
oxidative degradation, resveratrol has poor stability (Davidov-Pardo, 2014; Francioso, 2014). Gallerate et al. developed oil-in-water microemulsions that contain whitening agents (kojic acid and arbutin) that are photosensitive. They assessed the photostability to UVB irradiation of both whitening agents in aqueous solutions and microemulsions. The stability of arbutin and kojic acid was found higher in microemulsions than in aqueous solutions. (Gallarate, 2004). Incorporating resveratrol into $\mathrm{ME}$ formulation can be one of the solution methods to overcome its physical stability problem (Chen, 2015). In addition, in a previous study, it is stated that nano-sized emulsions can protect resveratrol from chemical degradation and are able to prevent inversion to inactive isomers (Sessa, 2011).

The aim of this study is to formulate and characterize co-surfactant free resveratrol-loaded MEs (RES-ME) for transdermal drug delivery. For revealing ME systems, triangle phase diagrams were drawn, and components that are essential for ME formulations such as oily phase, aqueous phase, and surfactant were settled at each tip of the triangle diagram. Subsequently, some characterization tests were conducted to identify the most stable formulation point on the phase diagram.

Natural oils that are considered as penetration enhancers can enable disruption of the SC lipid structure by fluidization and slackening mechanism and provide delivery of active ingredients into underly of SC to achieve successful topical delivery (Lane, 2013). Since containing oleic acid that enhances skin penetration, olive oil was selected as the oil phase (Cicero, 2018). Surface-active agents contribute maintain formulation stability while facilitating increased disruption of SC lipids (Lane, 2013). To provide phase stabilization in the oil-in-water MEs, utilizing a surface-active agent that has an hydrophilic-lipophilic balance (HLB) value of $\geq 12$ is more suitable (Rani, 2019; Zhang, 2015). In this study, since HLB values of Tween 80 is 15, it was selected as surfactant phase. In addition, Tween 80 is a non-ionic surfactant. The risk of skin irritation is very low. Therefore, Tween 80 is frequently chosen as a surface-active agent during the formulation of topical/transdermal products. (Lemerya, 2015).

ME formulations have been tested in terms of stability; the most stable formulations were chosen to be incorporated with resveratrol. Characterization tests such as droplet size, droplet size distribution, zeta potential, viscosity, $\mathrm{pH}$, and conductivity were performed for formulations.

\section{MATERIAL \& METHOD}

\section{Material}

Trans-resveratrol \%98 was gifted from Biota Laboratories (Istanbul, Republic of Turkey), Polysorbate 80 (Tween $80^{\circ}$ ) was used as surfactant, and olive oil was used as an oily phase in delivery systems and purchased from Merck KGaA, Darmstadt, Germany. Distilled water was used as an aqueous phase and was produced using a water purification system Pure Lab UV/UF lanpure (USA). All other chemicals were of analytical reagent grade or higher.

\section{Triangle Phase Diagram}

Firstly, a triangular phase diagram should be drawn up to preparation ME formulations. Thus, suitable ME area and therefore the amount of the ingredients in the formulation is determined. Point studies were utilized to determine the ME area in this research. Aqua, oil and surfactant were used for each tip of the triangle. Some points were determined on the triangle phase diagram, and formulations comprised according to rates these points. The aqueous phase was added drop by drop to predetermined rates of the oil phase and surfactant mixing at magnetic 
stirrer. Consist of oil, aqua, and surfactant mixture was continued to mix for a while by increase mixing speed. One hundred nine formulations were prepared by mixing the specified weight of each component in small glass vials. Formulated MEs were evaluated visually at room temperature, transparent and isotropic formulations were considered ME. The ME area was drawn at the triangle phase diagram by using CHEMIX School version 4.00.

\section{Formulation of MEs}

Tween 80 and olive oil was stirred at $600 \mathrm{rpm}$ continuously heating at $40^{\circ} \mathrm{C}$ until obtaining homogeneous mixture at a magnetic stirrer. At the same temperature predetermined extent distilled water was added drop by drop with waiting periods to the mixture of tween 80 and olive oil at $1250 \mathrm{rpm}$ mixing speed. The formulations were held at room temperature $\left(25 \pm 0.5^{\circ} \mathrm{C}\right)$ for $24 \mathrm{~h}$, consequent day formulations assessed visually whether any phase separation or other physical instability of formulations (Parmar, 2016).

Formulations were selected from areas that are known to present favourable properties for topical drug delivery. Eighteen formulations selected from the ME area and equilibrated in ambient conditions for 72 hours, then they were evaluated according to their flow properties, phase separation, and other stability problem (Table 1). Formulations that remained after the first evaluation, centrifuged at $15000 \mathrm{rpm}$ for 15 minutes. MEs that passed the centrifugation tests were examined for droplet size, and optimized ME formulation was determined for $\mathrm{pH}$, viscosity, and conductivity test. Optimization of experimental MEs was performed according to criteria of MEs droplet size, single peak distribution of droplet size.
Table 1. Formulations' components rates for ME systems

\begin{tabular}{|l|c|c|c|}
\hline Code & Tween 80 $\mathbf{g})$ & Olive Oil $(\mathrm{g})$ & Distilled Water $(\mathrm{g})$ \\
\hline ME1 & 16 & 4 & 80 \\
\hline ME2 & 18 & 2 & 80 \\
\hline ME3 & 20 & 2 & 78 \\
\hline ME4 & 20 & 1.4 & 78.6 \\
\hline ME5 & 20 & 1.3 & 78.7 \\
\hline ME6 & 23 & 1.8 & 75.2 \\
\hline ME7 & 20 & 1.6 & 78.4 \\
\hline ME8 & 20.4 & 1.6 & 77.9 \\
\hline ME9 & 20.8 & 1.6 & 77.6 \\
\hline ME10 & 21 & 1.2 & 77.8 \\
\hline ME11 & 22.6 & 1.8 & 75.6 \\
\hline ME12 & 24 & 2 & 74 \\
\hline ME13 & 24.2 & 2.8 & 73 \\
\hline ME14 & 28 & 2 & 70 \\
\hline ME15 & 32 & 2 & 66 \\
\hline ME16 & 34 & 2 & 64 \\
\hline ME17 & 36 & 2 & 62 \\
\hline ME18 & 40 & 2 & 58 \\
\hline
\end{tabular}

Formulation of MEs incorporating resveratrol

Incorporation of resveratrol into MEs was performed by dissolving resveratrol in olive oil and Tween 80 mixture. Predetermined amount of distilled water were added drop by drop to the mixture of oil, surfactant and dissolved resveratrol. Thus, optimized composition ME with resveratrol was formulated (RES-ME). Adult dietary dose of resveratrol, for cardiovascular disease, anti-oxidant, anti-inflammatory, anti-tumor activity against colorectal cancer cells (Langcake \& Pryce, 1976; Mukhopadhyay, 2010) is around 20 - $50 \mathrm{mg}$ (Walle, 2004). Therefore, the target content of resveratrol in ME was set to be $0.05 \%$ $(w / w)$. The formulations were held at ambient temperature for 72 hours to assess either exist for any sign of phase separation, turbidity, or gelation.

\section{Physical Characterization of MEs}

The pre-stability test was performed on prepared formulations to eliminate unstable formulations. The elicited formulations were centrifuged at $15000 \mathrm{rpm}$ for 15 minutes using Hettich Zentrifügen D7200 to 
determine either any stability problem or not. Formulations that survived after the centrifuges test was selected to perform thermal tests. Thermal tests are the second stage of accelerated of stability tests. Formulations were put in the water bath at $40^{\circ} \mathrm{C}$ the temperature was increased $10^{\circ} \mathrm{C}$ every 30 minutes till $80^{\circ} \mathrm{C}$ (Figueiredo, 2016). The formulations were evaluated in terms of appearance after returning to room temperature $\left(25 \pm 2{ }^{\circ} \mathrm{C}\right)$. Formulations that not observed stability problems such as sedimentation, phase separation were selected for subsequent tests.

Droplet size, $\mathrm{pH}$, viscosity, conductivity, and determination of oil-in-water $(\mathrm{O} / \mathrm{W})$ type were tested to evaluate the quality of MEs.

The droplet size determines the rate of drug release and absorption. Therefore, it is a crucial factor in the performance of the emulsification system. (Shah, 1994). A glass cuvette was used to measure droplet size, polydispersity index (PDI), and zeta potential in the Zetasizer device. Formulations were diluted at the rate of 1:100 with distilled water (Figueiredo, 2016). Droplet size, zeta-potential, and PDI of formulated MEs were measured applying dynamic light scattering technique, using Zetasizer Nano ZS 90 particle size analyzer (Malvern). Measurements were performed at ambient conditions temperature, and each formulation was scanned ten times. Measurements were repeated three times to obtain mean values.

Brookfield DV3T Rheometer device was used to examine the rheological properties of formulations that remain after the stability test and accepted for their droplet sizes. Hanna HI 2002-02 Edge device was utilized to determine the $\mathrm{pH}$ of formulations at ambient temperature.

The type of ME (oil-in-water or water-in-oil) was determined by performing a dye test with Sudan III and Methylene blue. In addition to the dye test, conductivity determination was performed using Eutech Instruments, PC 2700 to confirm the type of MEs.

\section{Statistical analysis}

For identification whether it is or not a significant difference between formulations binary comparing t-test was performed with $\mathrm{p}<0.05$ as a minimum level of significance. All statistical computing was carried out manually and utilizing the Excel program (MS, USA).

\section{RESULTS AND DISCUSSION}

Variety structures can be exhibited by mixing oil, surfactant, and aqua. Such as macro emulsions and MEs dispersion systems are occurred by mixing components at varied rates. Elicited formulations can be recognized by a simple visual assessment of their physical appearance. MEs are translucent/transparent and isotropic homogenous dispersion systems.

Triangle phase diagrams are very useful for determining the area of MEs (Rani, 2019). Furthermore, identifying the concentration range of the excipients that facilitate the formation of nano-sized emulsions is provided by these diagrams (Ibrahim, 2018). 


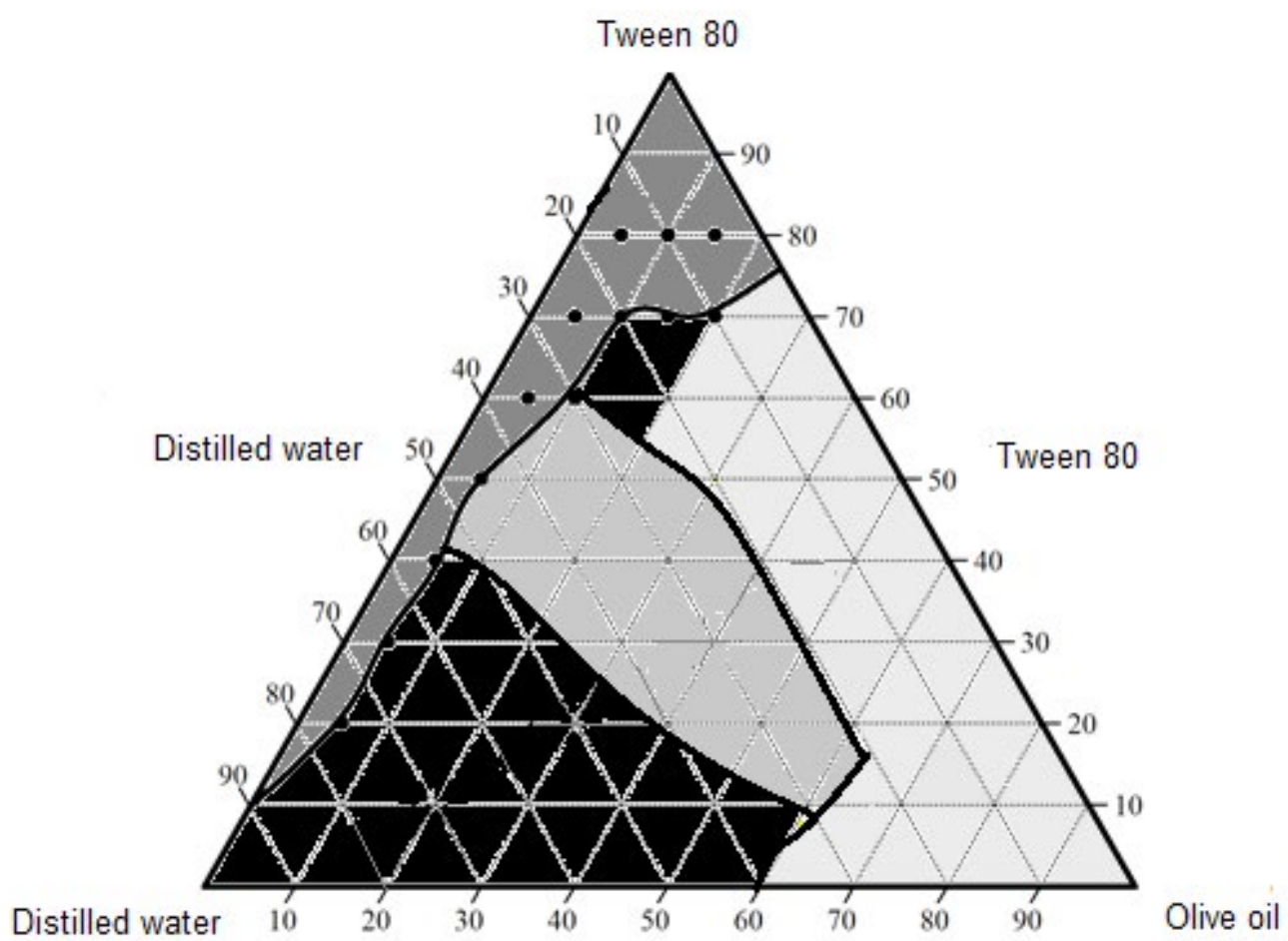

Olive oil

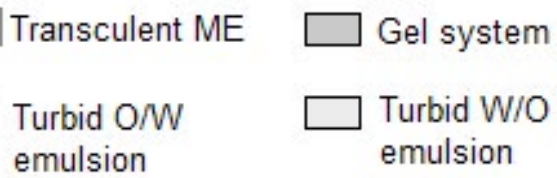

Figure 1. Triangle phase diagrams of olive oil, Tween 80 and aqua

There is a narrow area on the triangle phase diagrams where transparent formulations can transpire shown in Figure 1. One of the reasons for the formation of transparent-looking microemulsions in a narrow area was attributed to the use of a single surfactant (Lawrence, 2000).

In the areas where oil and aqua concentrations were low, and surfactant concentration was high, translucent/transparent systems formed. While o/w emulsion occurred at the middle up and left area those were riched with water of the diagram, w/o emulsion occurred at the right of the triangle phase diagram where riched by oil. Since Tween 80 has a high HLB value, which underpins the formation of $\mathrm{o} / \mathrm{w}$ emulsions large $\mathrm{o} / \mathrm{w}$ emulsion area occurred in the triangle phase diagram (Lawrence, 2000). It was observed that the mixtures with 20-60\% water content had gel structures. The water content of systems was above $60 \%$ impaired the gel form, and resulted in dispersing of the swelled gel. When the water content of systems was below $20 \%$ not enough to form the gel structure. Because more than 20\% water content was required in the dispersion systems to hydrate the polyoxyethylene groups (Syed, 2014).Water content above $\% 75$ revealed dispersion systems that have better flow properties. However, to find out transparent MEs systems, the rate of Tween 80 to olive oil should be higher than 12:1.

Olive oil content above $\% 2$ revealed dispersion systems that were not quite transparent. Moreover, 
a high concentration oil phase gives rise to produce reverse micelles (Hegde, 2013), which creates an obstacle for developing topical MEs.

To optimize viscosity properties and droplet size of systems, surfactant type should be chosen well. Tween 80 is a non-ionic surface active ingredient that is safe for biological tissues and skin, and it was chosen as a surfactant for the stabilization of MEs (Flanagan, 2006; Lawrence, 2000). Tween 80 is a hydrophilic surfactant since the hydroxyl groups on the sorbitan ring are replaced by bulky polyoxyethylene groups. Due to hydrophilic constitute, Tween 80 is more suitable to create an oil-in-water emulsion. The type of oil according to its hydrocarbon chain length can influence the stability of dispersion systems. Tween 80 can be single adequate to form o/w microemulsions due to having a long chain (Lawrence, 1994; Malcolmson, 1993, 1995; Tenjarla, 1999). ME systems can be achieved by carefully choosing components. Microemulsion systems based on natural and skin-beneficial oils could potentially provide additional benefits over microemulsion systems based on other oils (Das, 2020; M Jayne Lawrence, 2000). Due to its several benefits for the skin and has been used safely since ancient times, olive oil was chosen as the oil phase (Gorini, 2019). In addition, olive oil increases disruption of SC lipid structure due to increasing oleic acid levels, and provided improving dermal molecules delivery (Van Staden, 2020). Oleic acid and isopropyl myristate are the most frequently selected components of the oily phase. (El Maghraby, 2008; Hathout, 2010; Heuschkel, 2008). However, since isopropyl myristate is considered comedogenic, it was not chosen as a surfactant in the present study (Nguyen, 2007). Oil and surfactant chain length compatibility is an essential factor that impacts elicit ME formulations (Bayrak, 2005). Olive oil has a high molecular weight because it contains mostly long-chain oleic acid triglycerides. Therefore, it is not too easy to formulate ME systems with olive oil (Cho, 2008; Syed, 2014).

Skin irritation can be induced by a topical or transdermal formulation that contains a high concentration surface active ingredient. Thus, using a high concentration of surfactant should be avoided in topical and transdermal formulations (Djekic, 2008; Kreilgaard, 2002). Additionally, co-surfactants can cause the destruction of a microemulsion upon dilution due to the partitioning of the co-surfactant out of the interfacial region into the continuous phase (Warisnoicharoen, 2000). Since the main aim of this study was the development of co-surfactant-free RES$\mathrm{ME}$, and have a knowledge that high concentration of surfactant increase skin irritation, formulations that have a low concentration surfactant were chosen.

ME4, ME5, ME6, ME7, ME8, ME9 formulations were selected for the centrifuge test. All formulations remained stable after the centrifugation. ME7 formulation was not sufficiently bright compared to other formulations.

The dispersed phase's droplet size, droplet size distribution, and zeta-potential essentially affect the comprising of MEs that have physical stability. (Balata, 2016; Mahapatra, 2014; Ujilestari, 2018). Droplet size measurement is considered one of the most crucial characterization tests of MEs due to influencing stability and release (Zaichik, 2018). Reducing droplet size contributes to increasing penetration of active ingredients through the skin (Kaur, 2019). The PDI demonstrates size distribution which is crucial for stability (Kaur, 2019). There is no exist fixed PDI values range for dermal drug delivery. However, while PDI $\leq 0.2$ is considered the ideal value for polymer-based nanoparticles that developed for transdermal drug delivery, PDI $<0.3$ is considered the ideal value for lipid-based carrier systems. (D. van Staden, 2020). Dynamic light scattering technique can detect cluster small particles as one large particle, therefore microscopic techniques can be more suitable for exceeded from PDI values range (0.05-0.7) that generally accepted pharmaceutical range (Danaei, 2018).

Formulations were examined in the Malvern Zetasizer to determine droplet size and droplet size dis- 
tribution. The droplet size of MEs was measured $24 \mathrm{~h}$ after formulation. Two-peak distribution droplet size was found out in ME4, ME5, and ME6 formulations.

Contrary to these formulations, single-peak droplet distribution was revealed in both ME8 and ME9 that were not incorporated with resveratrol (Figure 2, 3). Physical characterization studies were performed to detect the effects of incorporating resveratrol into MEs dispersed phase. Such as phase separation, cracking, and creaming instability problems were not observed after incorporate resveratrol in ME formulations. Mean droplet size values decreased with the incorporation of resveratrol in both formulations. A statistically significant difference was found for the average droplet sizes of ME8 and ME8-RES formulations $(\mathrm{p}<0.05)$. On the contrary, the difference was not considered as statistically significant $(\mathrm{p}>0.05)$ between the average droplet size of ME9 formulation incorporating with resveratrol or without resveratrol. It was occurred high possibility due to the solubility ability of the surfactant component. Tween 80 increased solubility of resveratrol in the ME formula- tions (Chen, 2015; Constantinides, 1995). Since resveratrol solubility increased as a result of surfactant function, resveratrol probably kept stay in the continuous phase and didn't settle in the interfacial layer that didn't result in increased droplet size (Juškaite, 2015; Saribey, 2021). In a previous study, the average droplet size ( $70.3-74.0 \mathrm{~nm}$ ) of microemulsions that did not contain co-surfactant was larger than in the present study (Cho, 2008). Also, the less quantity Tween 80 was used in the present study $(20.8 \mathrm{~g})$ than in the previous study (33.8 g).

Resveratrol-containing formulations' droplet size measurements results showed the existence of single-peak droplet distribution in formulations 72 hours after formulation. In the present study, after incorporating resveratrol in ME, the droplet size (12.27 \pm 0.07 ) was smaller than in the previously conducted study (116.83 \pm 0.23$)$ (Juškaitè, 2015). The homogeneous distribution of the internal phase in ME formulations is demonstrated by low PDI values and single peaked dispersion droplet size. (Thakkar, 2014).

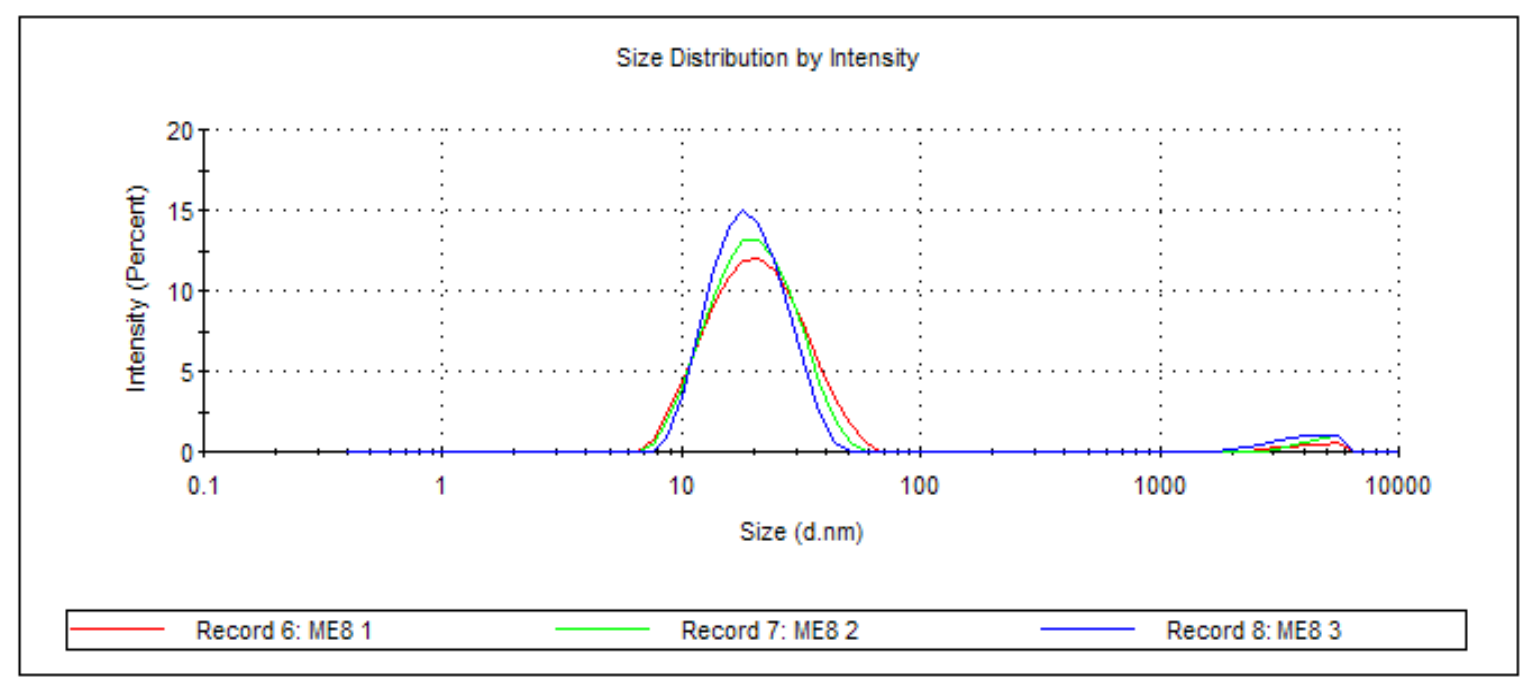

Figure 2. ME8 formulation's droplet size distribution 


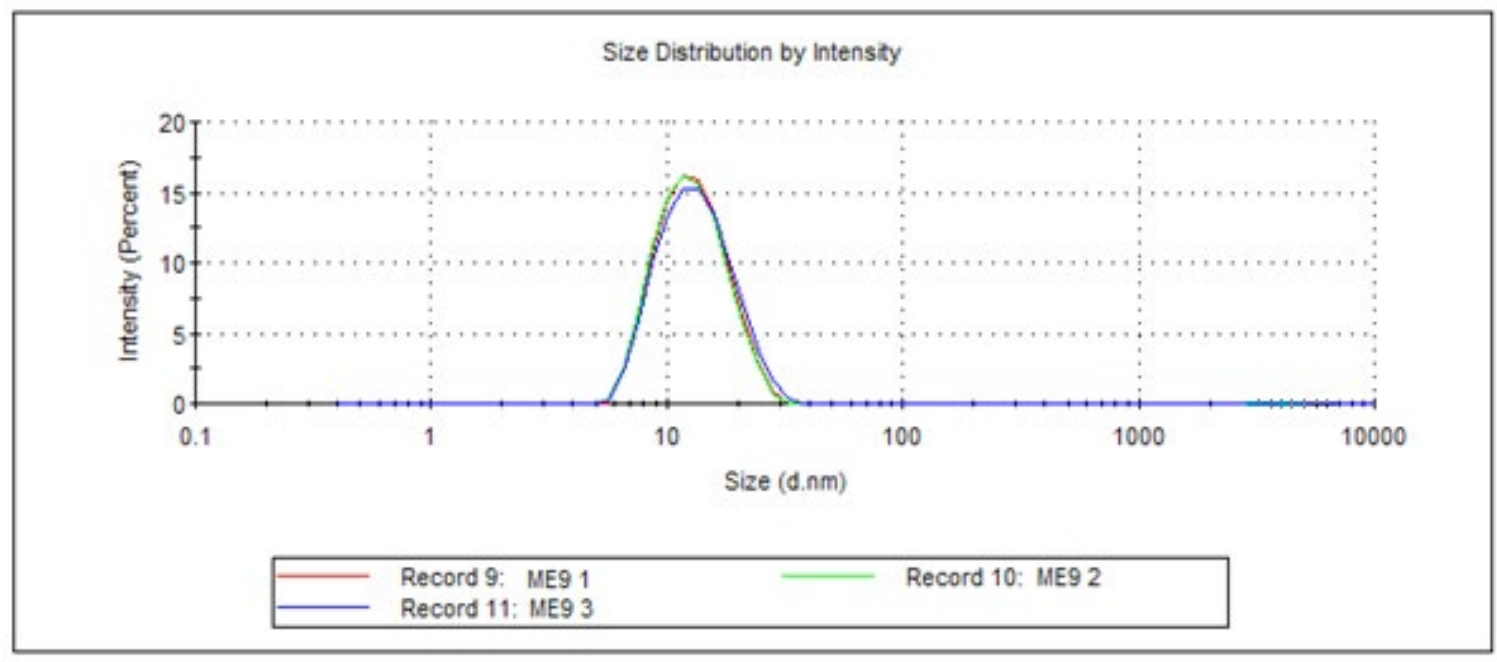

Figure 3. ME9 formulation's droplet size distribution

When zeta potential has high values for both negative $(<-30 \mathrm{mV})$ or positive $(>30 \mathrm{mV})$ increases electrostatic pushing between droplets. Hence, unfavorable coagulation is prevented (Sharma, 2014). Since the skin charge is negative, positively charged formulations theoretically must increase the affinity between the skin and applied formulations (Carter, 2019). Nevertheless, free fatty acids in the oil phase are negatively charged (Umerska, 2016). Moreover, free fatty acids are penetration enhancers due to functions of disrupting SC layers (van Zyl, 2016). Therefore, negatively charged formulations are slow- er penetration enhancers than positively charged formulations (Carter, 2019). The zeta potential values were acceptable ranges (Table 2), and significant differences could not be found out between formulations' those not incorporating resveratrol, zeta potential values. The zeta potential values were similar to published data for another type of ME formulation (Kural, 2011). Preventing droplet coalescence during the formulation development is possible with a higher negative charge (Ganta, 2014). ME9 coded formulation's zeta potential values seemed more suitable than ME8 in terms of stability.

Table 2. Droplet size, PDI and zeta potential of optimized formulations and RES loaded formulations

\begin{tabular}{l|c|c|c|c|}
\hline & ME8 & \%0.05 RES-ME8 & ME9 & \%0.05 RES-ME9 \\
\hline Droplet size (nm) & $19,22 \pm 0,07$ & $12,34 \pm 0,18$ & $12,42 \pm 0,16$ & $12,27 \pm 0,07$ \\
\hline PDI & $0,200 \pm 0,01$ & $0,103 \pm 0,004$ & $0,145 \pm 0,001$ & $0,046 \pm 0,003$ \\
\hline Zeta-Potential (mV) & $-12,2$ & $-1,31$ & $-10,6$ & $-2,13$ \\
\hline Zeta Deviation (mV) & 6,08 & 71,3 & 7,45 & 3,76 \\
\hline
\end{tabular}

ME8 and ME9 formulations were evaluated for $\mathrm{pH}$, conductivity, and viscosity. $5.0-9.0$ is a suitable $\mathrm{pH}$ value range for dermal drug delivery (Rastogi, 2014). However, the optimal $\mathrm{pH}$ for dermal drug delivery systems is $4-5$ range that is close to natural skin $\mathrm{pH}$ values (Sheshala, 2019). $\mathrm{pH}$ values of both formu- lations were similar, and no statistically significant difference was observed ( $>0.05)$ (Table 3). Likewise, conductivity values were very close to each other. The $\mathrm{pH}$ of optimized MEs was $6-7$ that acceptable values physiologically. 
Table 3. Characteristic of optimized formulations and RES loaded formulations

\begin{tabular}{l|l|l|ll|}
\hline \multicolumn{1}{l}{ ME8 } & \%0.05 RES-ME8 & \multicolumn{1}{l}{ ME9 } & \multicolumn{1}{l}{ \%0.05 RES-ME9 } \\
\hline pH & $6,36 \pm 0,03$ & $6,30 \pm 0.17$ & $6,28 \pm 0.01$ & $6,22 \pm 0.007$ \\
\hline Conductivity $(\mu \mathrm{S} / \mathrm{cm})$ & $127,7 \pm 0,1$ & $123.4 \pm 0,05$ & $124,3 \pm 0,08$ & $122,8 \pm 0,06$ \\
\hline Viscosity $(\mathbf{c P})$ & $11,77 \pm 0,15$ & $15,11 \pm 1,23$ & $12,07 \pm 0,26$ & $16,40 \pm 0,48$ \\
\hline
\end{tabular}

Average conductivity close to $100 \mu \mathrm{S} / \mathrm{cm}$ demonstrates MEs type are oil-in-water (Patel, 2009; Salimi, 2013). Additionally, a dye test was performed to detect the type of microemulsion formulations. Sudan III was poured a very small amount on formulation and examined on the optic microscope. Since the outer phase of the ME was an aqueous phase a structure that uncolored was observed, and droplets that constitute the internal phase were red was due to the oily phase.

Viscosity refers to the internal friction of the fluid. Viscosity has an effect on both flow resistance and emulsification. (Perazzo, 2015). In microemulsions, a correlation exists between droplet size and viscosity, accordingly as droplet size decreases viscosity increases (D. van Staden, 2020). As droplet size decreases, penetration of active ingredients through skin increases, but high viscosity formulations induce occlusivity (D. van Staden, 2020).

The rheological behavior of microemulsion systems indicates non-Newtonian flow, that as share rate increases viscosity decrease. (Ambade, 2008). The viscosity values were between 11 and $17 \mathrm{cP}$, and acceptable ranges for MEs. The viscosity values were similar to published data for another type of ME formulation (Liu, 2011). The non-significant difference between values of ME8 and ME9 viscosity was revealed possibly due to water content. The viscosity values of nano-sized emulsions decrease with increased water content (Bakshi, 2018).

\section{CONCLUSION}

Formulations that droplet sizes smaller than 50 $\mathrm{nm}$ and having a transparent appearance considered as ME. The triangle phase diagram saves time by reducing the number of experiments. It also facilitates the formation of optimal MEs with favorable properties. Phase diagrams of the components with different ratios have been successfully prepared to determine the ME regions. The optimal amounts of the components were determined to form the most stable ME formulation. The type of and quantities of surfactant, oily phase, and the aqueous phase directly impact the appearance, droplet size, droplet size distribution, type of formulations.

Resveratrol ME was developed, optimized, and characterized for application through the skin. ME prepared by using olive oil, Tween 80 , and distilled water in the ratio 1.6: 20.8: 77.6 (in g) was considered as an optimized formulation (ME9) in terms of reducing problems associated with stability.

It is planned in vivo studies to identify resveratrol quantity in plasma in the next stage. This study will be very useful and promising to formulate resveratrol MEs as transdermal delivery systems both in the pharmaceutical industry and cosmetics products.

\section{ACKNOWLEDGMENTS}

This work was funded by the Scientific Research Projects Unit of Istanbul University (Project code: TDK-2020-35272).

\section{CONFLICT OF INTEREST}

The authors declare that there is no conflict of interest.

\section{AUTHOR CONTRIBUTION STATEMENT}

Research concept and design, data collecting, experimenting, data analysis and interpretation, manuscript draft, final approval (BS). Research concept and design, data, data analysis, and interpretation, final approval (FGY). Research concept and design, data, data analysis, and interpretation, final approval (İTD). 


\section{REFERENCES}

Ambade, K. W., Jadhav, S. L., Gambhire, M. N., Kurmi, S. D., Kadam, V. J., \& Jadhav, K. R. (2008). Formulation and evaluation of flurbiprofen microemulsion. Current Drug Delivery, 5(1), 32-41. doi:10.2174/156720108783331032

Bakshi, P., Jiang, Y., Nakata, T., Akaki, J., Matsuoka, N., \& Banga, A. K. (2018). Formulation Development and Characterization of Nanoemulsion-Based Formulation for Topical Delivery of Heparinoid. Journal of Pharmaceutical Science, 107(11), 28832890. doi:10.1016/j.xphs.2018.07.015

Balata, G. F., Essa, E. A., Shamardl, H. A., Zaidan, S. H., \& Abourehab, M. A. S. (2016). Self-emulsifying drug delivery systems as a tool to improve solubility and bioavailability of resveratrol. Drug Design Development and Therapy, 10. doi:10.2147/ Dddt.S95905

Baur, J. A., Pearson, K. J., Price, N. L., Jamieson, H. A., Lerin, C., Kalra, A., . . Sinclair, D. A. (2006). Resveratrol improves health and survival of mice on a high-calorie diet. Nature, 444(7117), 337-342. doi:10.1038/nature05354

Baur, J. A., \& Sinclair, D. A. (2006). Therapeutic potential of resveratrol: the in vivo evidence. Nature Reviews Drug Discovery , 5(6), 493-506. doi:10.1038/ $\operatorname{nrd} 2060$

Baxter, R. A. (2008). Anti-aging properties of resveratrol: review and report of a potent new antioxidant skin care formulation. Journal of Cosmetic Dermatology, 7(1), 2-7. doi:10.1111/j.14732165.2008.00354.x

Bayrak, Y., \& Iscan, M. (2005). Studies on the phase behavior of the system non-ionic surfactant/alcohol/alkane/H2O. Colloids and Surfaces a-Physicochemical and Engineering Aspects, 268(1-3), 99103. doi:10.1016/j.colsurfa.2005.06.021

Benson, H. A. (2012). Skin structure, function, and permeation. Topical and Transdermal Drug Delivery: Principles and Practice, 1st ed.; Benson, HAE, Watkinson, AC, Eds, 1-22.
Carter, P., Narasimhan, B., \& Wang, Q. (2019). Biocompatible nanoparticles and vesicular systems in transdermal drug delivery for various skin diseases. International Journal of Pharmaceutics , 555, 49-62. doi:10.1016/j.ijpharm.2018.11.032

Chen, Y., Zhang, H., Yang, J., \& Sun, H. (2015). Improved antioxidant capacity of optimization of a self-microemulsifying drug delivery system for resveratrol. Molecules, 20(12), 21167-21177.

Cho, Y. H., Kim, S., Bae, E. K., Mok, C., \& Park, J. (2008). Formulation of a cosurfactant-free $\mathrm{o} / \mathrm{w}$ microemulsion using nonionic surfactant mixtures. Journal of Food Science, 73(3), E115-E121.

Cicero, N., Albergamo, A., Salvo, A., Bua, G. D., Bartolomeo, G., Mangano, V., . . Dugo, G. (2018). Chemical characterization of a variety of coldpressed gourmet oils available on the Brazilian market. Food Research International, 109, 517-525. doi:10.1016/j.foodres.2018.04.064

Constantinides, P. P. (1995). Lipid microemulsions for improving drug dissolution and oral absorption: physical and biopharmaceutical aspects. Pharmaceutical Research, 12(11), 1561-1572.

Danaei, M., Dehghankhold, M., Ataei, S., Hasanzadeh Davarani, F., Javanmard, R., Dokhani, A., . . Mozafari, M. R. (2018). Impact of Particle Size and Polydispersity Index on the Clinical Applications of Lipidic Nanocarrier Systems. Pharmaceutics, 10(2). doi:10.3390/pharmaceutics10020057

Das, S., Chaudhury, A., \& Ng, K.-Y. (2011). Polyethyleneimine-modified pectin beads for colon-specific drug delivery: In vitro and in vivo implications. Journal of Microencapsulation, 28(4), 268-279.

Das, S., Lee, S. H., Chow, P. S., \& Macbeath, C. (2020). Microemulsion composed of combination of skin beneficial oils as vehicle: Development of resveratrol-loaded microemulsion based formulations for skin care applications. Colloids and Surfaces B: Biointerfaces, 194, 111161. 
Das, S., Lin, H. S., Ho, P. C., \& Ng, K. Y. (2008). The impact of aqueous solubility and dose on the pharmacokinetic profiles of resveratrol. Pharmaceutical Research, 25(11), 2593-2600. doi:10.1007/ s11095-008-9677-1

Das, S., \& Ng, K. Y. (2010a). Colon-specific delivery of resveratrol: optimization of multi-particulate calcium-pectinate carrier. International Journal of Pharmacology, 385(1-2), 20-28. doi:10.1016/j. ijpharm.2009.10.016

Das, S., \& Ng, K. Y. (2010b). Impact of glutaraldehyde on in vivo colon-specific release of resveratrol from biodegradable pectin-based formulation. Journal of Pharmaceutical Sciences, 99(12), 49034916. doi:10.1002/jps.22212

Das, S., \& Ng, K. Y. (2010c). Resveratrol-loaded calcium-pectinate beads: effects of formulation parameters on drug release and bead characteristics. Journal of Pharmaceutical Sciences, 99(2), 840860. doi:10.1002/jps.21880

Das, S., Ng, K. Y., \& Ho, P. C. (2010). Formulation and optimization of zinc-pectinate beads for the controlled delivery of resveratrol. AAPS PharmSciTech, 11(2), 729-742. doi:10.1208/s12249-010-9435-7

Davidov-Pardo, G., \& McClements, D. J. (2014). Resveratrol encapsulation: Designing delivery systems to overcome solubility, stability and bioavailability issues. Trends in Food Science \& Technology, 38(2), 88-103. doi:10.1016/j.tifs.2014.05.003

Delmas, D., Lancon, A., Colin, D., Jannin, B., \& Latruffe, N. (2006). Resveratrol as a chemopreventive agent: A promising molecule for fighting cancer. Current Drug Targets, 7(4), 423-442. doi:Doi $10.2174 / 138945006776359331$

Djekic, L., \& Primorac, M. (2008). The influence of cosurfactants and oils on the formation of pharmaceutical microemulsions based on PEG-8 caprylic/capric glycerides. International Journal of Pharmaceutics, 352(1-2), 231-239.
El Maghraby, G. M. (2008). Transdermal delivery of hydrocortisone from eucalyptus oil microemulsion: effects of cosurfactants. International Journal of Pharmaceutics, 355(1-2), 285-292.

Figueiredo, K. A., Neves, J. K. O., da Silva, J. A., de Freitas, R. M., \& Carvalho, A. L. M. (2016). Phenobarbital loaded microemulsion: development, kinetic release and quality control. Brazilian Journal of Pharmaceutical Sciences, 52(2), 251-263. doi:10.1590/S1984-82502016000200003

Fisher, G. J., Wang, Z. Q., Datta, S. C., Varani, J., Kang, S., \& Voorhees, J. J. (1997). Pathophysiology of premature skin aging induced by ultraviolet light. New England Journal of Medicine, 337(20), 14191428. doi:10.1056/NEJM199711133372003

Flanagan, J., \& Singh, H. (2006). Microemulsions: a potential delivery system for bioactives in food. Critical Reviews in Food Science and Nutrition, 46(3), 221-237.

Francioso, A., Mastromarino, P., Restignoli, R., Boffi, A., d'Erme, M., \& Mosca, L. (2014). Improved stability of trans-resveratrol in aqueous solutions by carboxymethylated $(1,3 / 1,6)$-beta-D-glucan. The Journal of Agricultural and Food Chemistry, 62(7), 1520-1525. doi:10.1021/jf404155e

Gallarate, M., Carlotti, M. E., Trotta, M., Grande, A., \& Talarico, C. (2004). Photostability of naturally occurring whitening agents in cosmetic microemulsions. Journal of Cosmetic Science, 55(2), 139-148.

Ganta, S., Talekar, M., Singh, A., Coleman, T. P., \& Amiji, M. M. (2014). Nanoemulsions in Translational Research-Opportunities and Challenges in Targeted Cancer Therapy. AAPS PharmSciTech, 15(3), 694-708. doi:10.1208/s12249-014-0088-9

Gorini, I., Iorio, S., Ciliberti, R., Licata, M., \& Armocida, G. (2019). Olive oil in pharmacological and cosmetic traditions. Journal of Cosmetic Dermatology, 18(5), 1575-1579. 
Hathout, R. M., Woodman, T. J., Mansour, S., Mortada, N. D., Geneidi, A. S., \& Guy, R. H. (2010). Microemulsion formulations for the transdermal delivery of testosterone. European Journal of Pharmaceutical Sciences, 40(3), 188-196.

Hegde, R. R., Verma, A., \& Ghosh, A. (2013). Microemulsion: new insights into the ocular drug delivery. International Scholarly Research Notices, 2013.

Heuschkel, S., Goebel, A., \& Neubert, R. H. (2008). Microemulsions-modern colloidal carrier for dermal and transdermal drug delivery. Journal of Pharmaceutical Sciences, 97(2), 603-631.

Ibrahim, T. M., Abdallah, M. H., El-Megrab, N. A., \& El-Nahas, H. M. (2018). Upgrading of dissolution and anti-hypertensive effect of Carvedilol via two combined approaches: self-emulsification and liquisolid techniques. Drug Development and Industrial Pharmacy, 44(6), 873-885. doi:10.1080/0 3639045.2017 .1417421

Jang, M., Cai, L., Udeani, G. O., Slowing, K. V., Thomas, C. F., Beecher, C. W., . . Pezzuto, J. M. (1997). Cancer chemopreventive activity of resveratrol, a natural product derived from grapes. Science, 275(5297), 218-220. doi:10.1126/science.275.5297.218

Juškaitè, V., Ramanauskienė, K., \& Briedis, V. (2015). Design and formulation of optimized microemulsions for dermal delivery of resveratrol. Evidence-Based Complementary and Alternative Medicine, 2015.

Kaur, R., \& Ajitha, M. (2019). Transdermal delivery of fluvastatin loaded nanoemulsion gel: Preparation, characterization and in vivo anti-osteoporosis activity. European Journal of Pharmaceutical Sciences, 136, 104956. doi:10.1016/j.ejps.2019.104956

Kreilgaard, M. (2002). Influence of microemulsions on cutaneous drug delivery. Advanced Drug Delivery Reviews, 54 Suppl 1, S77-98. doi:10.1016/ s0169-409x(02)00116-3
Kural, F. H., \& Gürsoy, R. N. (2011). Formulation and Characterization of Surfactin-Containing Self-Microemulsifying Drug Delivery Systems SF-SMEDDS. Hacettepe Üniversitesi Eczacilik Fakültesi Dergisi(2), 171-186.

Lane, M. E. (2013). Skin penetration enhancers. International Journal of Pharmaceutics, 447(1-2), 12-21.

Langcake, P., \& Pryce, R. (1976). The production of resveratrol by Vitis vinifera and other members of the Vitaceae as a response to infection or injury. Physiological Plant Pathology, 9(1), 77-86.

Lawrence, M. J. (1994). Surfactant systems: microemulsions and vesicles as vehicles for drug delivery. European Journal of Drug Metabolism and Pharmacokinetics, 19(3), 257-269.

Lawrence, M. J., \& Rees, G. D. (2000). Microemulsion-based media as novel drug delivery systems. Advanced Drug Delivery Reviews, 45(1), 89-121.

Lawrence, M. J., \& Rees, G. D. (2012). Microemulsion-based media as novel drug delivery systems. Advanced Drug Delivery Reviews, 64, 175-193. doi:10.1016/j.addr.2012.09.018

Lemerya, E., Briancon, S., Chevalier, Y., Bordes, C., Oddos, T., Gohier, A., \& Bolzinger, M. A. (2015). Skin toxicity of surfactants: Structure/toxicity relationships. Colloids and Surfaces a-Physicochemical and Engineering Aspects, 469, 166-179. doi:10.1016/j.colsurfa.2015.01.019

Liu, C. H., \& Chang, F. Y. (2011). Development and characterization of eucalyptol microemulsions for topic delivery of curcumin. Chemical and Pharmaceutical Bulletin(Tokyo), 59(2), 172-178. doi:10.1248/cpb.59.172

Mahapatra, A. K., Murthy, P. N., Swadeep, B., \& Swain, R. (2014). Self-emulsifying drug delivery systems (SEDDS): An update from formulation development to therapeutic strategies. International Journal of PharmTech Research, 6(2), 546-568. 
Malcolmson, C., \& Lawrence, M. J. (1993). A comparison of the incorporation of model steroids into non-ionic micellar and microemulsion systems. Journal of Pharmacy and Pharmacology, 45(2), 141-143.

Malcolmson, C., \& Lawrence, M. J. (1995). Three-component non-ionic oil-in-water microemulsions using polyoxyethylene ether surfactants. Colloids and surfaces B: Biointerfaces, 4(2), 97-109.

Mukhopadhyay, P., Mukherjee, S., Ahsan, K., Bagchi, A., Pacher, P., \& Das, D. K. (2010). Restoration of altered microRNA expression in the ischemic heart with resveratrol. Plos One, 5(12), e15705.

Ndiaye, M., Philippe, C., Mukhtar, H., \& Ahmad, N. (2011). The grape antioxidant resveratrol for skin disorders: promise, prospects, and challenges. $A r$ chives of Biochemistry and Biophysics, 508(2), 164170. doi:10.1016/j.abb.2010.12.030

Nguyen, S. H., Dang, T. P., \& Maibach, H. I. (2007). Comedogenicity in rabbit: some cosmetic ingredients/vehicles. Cutaneous and ocular toxicology, 26(4), 287-292.

Parmar, K., Patel, J., \& Sheth, N. (2015). Self nano-emulsifying drug delivery system for Embelin: Design, characterization and in-vitro studies. Asian Journal of Pharmaceutical Sciences, 10(5), 396-404. doi:10.1016/j.ajps.2015.04.006

Patel, M. R., Patel, R. B., Parikh, J. R., Solanki, A. B., \& Patel, B. G. (2009). Effect of formulation components on the in vitro permeation of microemulsion drug delivery system of fluconazole. AAPS PharmSciTech, 10(3), 917-923. doi:10.1208/ s12249-009-9286-2

Patravale, V. B., \& Mandawgade, S. D. (2008). Novel cosmetic delivery systems: an application update. International Journal of Cosmetic Science, 30(1), 19-33. doi:10.1111/j.1468-2494.2008.00416.x
Perazzo, A., Preziosi, V., \& Guido, S. (2015). Phase inversion emulsification: Current understanding and applications. Advances in Colloid and Interface Science, 222, 581-599. doi:10.1016/j. cis. 2015.01 .001

Rani, S., Rana, R., Saraogi, G. K., Kumar, V., \& Gupta, U. (2019). Self-Emulsifying Oral Lipid Drug Delivery Systems: Advances and Challenges. AAPS PharmSciTech, 20(3), 129. doi:10.1208/s12249. 019-1335-x

Rastogi, V., \& Yadav, P. (2014). Transdermal drug delivery system: An overview. Asian Journal of Pharmaceutics, 6(3), 161-170.

Salimi, A., Sharif Makhmal Zadeh, B., \& Moghimipour, E. (2013). Preparation and characterization of cyanocobalamin (vit B12) microemulsion properties and structure for topical and transdermal application. Iranian Journal of Basic Medical Sciences, 16(7), 865-872.

Saribey, G., Kahraman, E., ERDAL, M., \& GÜNGÖR, S. (2021). Design and characterisation of colloidal nanocarriers for enhanced skin delivery of etodolac. Journal of Research in Pharmacy, 25(1), https://doi.org/10.35333/jrp.2021.289

Sessa, M., Tsao, R., Liu, R., Ferrari, G., \& Donsì, F. (2011). Evaluation of the stability and antioxidant activity of nanoencapsulated resveratrol during in vitro digestion. Journal of Agricultural and Food Chemistry, 59(23), 12352-12360.

Shah, N., Carvajal, M., Patel, C., Infeld, M., \& Malick, A. (1994). Self-emulsifying drug delivery systems (SEDDS) with polyglycolyzed glycerides for improving in vitro dissolution and oral absorption of lipophilic drugs. International Journal of Pharmaceutics, 106(1), 15-23.

Sharma, S., Shukla, P., Misra, A., \& Mishra, P. R. (2014). Interfacial and colloidal properties of emulsified systems: pharmaceutical and biological perspective. In Colloid and interface science in pharmaceutical research and development (pp. 149-172): Elsevier. 
Sheshala, R., Anuar, N. K., Abu Samah, N. H., \& Wong, T. W. (2019). In Vitro Drug Dissolution/ Permeation Testing of Nanocarriers for Skin Application: a Comprehensive Review. AAPS PharmSciTech, 20(5), 164. doi:10.1208/s12249019-1362-7

Singh, M. K., Chandel, V., Gupta, V., \& Ramteke, S. (2010). Formulation development and characterization of microemulsion for topical delivery of Glipizide. Der Pharmacia Lettre, 2(3), 33-42.

Solans, C., Morales, D., \& Homs, M. (2016). Spontaneous emulsification. Current Opinion in Colloid \& Interface Science, 22, 88-93.

Surber, C., \& Kottner, J. (2017). Skin care products: What do they promise, what do they deliver. Journal of Tissue Viability, 26(1), 29-36. doi:10.1016/j. jtv.2016.03.006

Syed, H. K., \& Peh, K. K. (2014). Identification of Phases of Various Oil, Surfactant/Co-Surfactants and Water System by Ternary Phase Diagram. Acta Poloniae Pharmaceutica, 71(2), 301-309.

Tenjarla, S. (1999). Microemulsions: an overview and pharmaceutical applications. Critical Reviews ${ }^{\mathrm{Tm}}$ in Therapeutic Drug Carrier Systems, 16(5).

Thakkar, P. J., Madan, P., \& Lin, S. S. (2014). Transdermal delivery of diclofenac using water-in-oil microemulsion: formulation and mechanistic approach of drug skin permeation. Pharmaceutical Development and Technology, 19(3), 373-384. doi:10.3109/10837450.2013.788658

Trommer, H., \& Neubert, R. H. (2006). Overcoming the stratum corneum: the modulation of skin penetration. A review. Skin Pharmacology and Physiology, 19(2), 106-121. doi:10.1159/000091978
Ujilestari, T., Dono, N. D., Ariyadi, B., Martien, R., \& Zuprizal. (2018). Formulation and characterization of self-nano emulsifying drug delivery systems of lemongrass (cymbopogon citratus) essential oil. Malaysian Journal of Fundamental and Applied Sciences, 14(3), 360-363. doi:DOI 10.11113/ mjfas.v14n3.1070

Umerska, A., Cassisa, V., Matougui, N., Joly-Guillou, M. L., Eveillard, M., \& Saulnier, P. (2016). Antibacterial action of lipid nanocapsules containing fatty acids or monoglycerides as co-surfactants. European Journal of Pharmaceutics and Biopharmaceutics, 108, 100-110. doi:10.1016/j.ejpb.2016.09.001

Van Staden, D., Du Plessis, J., \& Viljoen, J. (2020). Development of a self-emulsifying drug delivery system for optimized topical delivery of clofazimine. Pharmaceutics, 12(6), 523.

van Zyl, L., du Preez, J., Gerber, M., du Plessis, J., \& Viljoen, J. (2016). Essential Fatty Acids as Transdermal Penetration Enhancers. Journal of Pharmaceutical Sciences, 105(1), 188-193. doi:10.1016/j. xphs.2015.11.032

Walle, T., Hsieh, F., DeLegge, M. H., Oatis, J. E., \& Walle, U. K. (2004). High absorption but very low bioavailability of oral resveratrol in humans. Drug Metabolism and Disposition, 32(12), 1377-1382.

Warisnoicharoen, W., Lansley, A., \& Lawrence, M. (2000). Nonionic oil-in-water microemulsions: the effect of oil type on phase behaviour. International Journal of Pharmaceutics, 198(1), 7-27.

Zaichik, S., Steinbring, C., Menzel, C., Knabl, L., Orth-Holler, D., Ellemunter, H., ... Bernkop-Schnurch, A. (2018). Development of self-emulsifying drug delivery systems (SEDDS) for ciprofloxacin with improved mucus permeating properties. International Journal of Pharmacology, 547(1-2), 282-290. doi:10.1016/j.ijpharm.2018.06.005 
Zhang, L., Zhang, L., Zhang, M., Pang, Y., Li, Z., Zhao, A., \& Feng, J. (2015). Self-emulsifying drug delivery system and the applications in herbal drugs. Drug Delivery, 22(4), 475-486. doi:10.3109/10717 544.2013 .861659
Zillich, O. V., Schweiggert-Weisz, U., Eisner, P., \& Kerscher, M. (2015). Polyphenols as active ingredients for cosmetic products. International Journal of Cosmetic Science, 37(5), 455-464. doi:10.1111/ ics. 12218 